\title{
EFEKTIFITAS KEBIJAKAN MONETER TERHADAP INFLASI DI INDONESIA
}

\author{
Oleh: \\ Andi Rachman Setyawan \\ Staff PT. Reliance Securities \\ E-mail/No. Hp: - /08179635191
}

\begin{abstract}
The purpose of this research is to determine the effect of monetary policy through the discount rate and reserve requirement by the Central Bank as well as the previous inflation towards the inflation rate, and to investigate the effectiveness of monetary policy through the discount rate and reserve requirement as well as the previous inflation in influencing the rate of inflation. The data that is used to determine the discount rate and reserve requirements affect inflation in Indonesia is using multiple linear regression model with the approach of the Partial Adjustment Model (PAM) and statistical (partial, simultaneous tests and the coefficient of determination) as well as classical assumption or econometrics (test normality, linearity, autocorrelation, multicolinearity and heteroscedasticity). From these results, it is known that monetary policy from the first quarter 1985 to first quarter 2010 was still less effective direct influence on inflation, this can be known from a partial test done even though the relationship of monetary policy is consistent with monetarist theory.
\end{abstract}

Keywords: inflation, discount rate, reserve requirement

\section{PENDAHULUAN}

Dari data Asian Development Bank tahun 2010 kondisi perekonomian Asia Tenggara tahun 2008 sampai tahun 2010 kurang stabil (lihat tabel 1.1 dan 1.2). Hal ini disebabkan oleh perekonomian global yang mengalami krisis ekonomi. Dengan adanya krisis ekonomi tersebut menyebabkan hargaharga kurang stabil yang kemudian timbul permasalahan inflasi. Menurut Murni (2006) inflasi adalah suatu kejadian yang menunjukkan kenaikan inflasi secara umum dan berlangsung secara terus menerus. Inflasi merupakan permasalahan ekonomi yang tidak dapat dihindari.

Berdasarkan data laju inflasi Asia Tenggara versi Asian Development Bank tahun 2008 sampai 2010 cukup tinggi yaitu $8,6 \%$ tahun 2008 , akan tetapi kondisi inflasi tersebut terus menurun hingga tahun 2009 pada angka 2,5\%. Inflasi Asia Tenggara pada tahun 2008 yang tinggi disumbang oleh Negaranegara seperti Cambodia 25\%, dan Viet Nam 23\% dan yang terendah adalah Negara Brunei Darussalam sebesar 2,7\%. Untuk tahun 2009 inflasi tertinggi terjadi di Negara Viet Nam sebesar 6,8\% dan terendah di Thailand sebesar $-0,5 \%$. Sedangkan peramalan inflasi kawasan Asia Tenggara pada tahun 2010 di kisaran angka $4,1 \%$.

Pertumbuhan Produk Domestik Bruto (PDB) kawasan ekonomi Asia Tenggara versi Asian Development Bank tahun 2010 untuk tahun 2008 sebesar 4,1\% dan tahun 2009 0,1\%. Menurunnya pertumbuhan ekonomi ini disebabkan oleh kondisi perekonomian global yang sedang mengalami krisis. Akan tetapi peramalan untuk tahun 2010 pertumbuhan ekonomi Asia Tenggara 
mulai meningkat kembali. Kondisi pertumbuhan ekonomi tertinggi kawasan Asia Tenggara tahun 2008 adalah Negara Laos sebesar 7,2\% dan terendah pada tahun yang sama adalah Brunei Darussalam sebesar $-1,9 \%$. Untuk tahun 2009 pertumbuhan ekonomi tertinggi dicapai oleh Negara Laos sebesar 5,5\% dan terendah pada tahun yang sama adalah Singapura sebesar $-5 \%$.

Melihat kondisi perekonomian Asia Tenggara pada tabel 1.1 dan 1.2 diatas maka bisa dikatakan bahwa perekonomian Asia Tenggara berfluktuasi. Kondisi perekonomian Indonesia dengan indikator ekonomi laju inflasi menempati ketiga pada tahun 2008 sebesar 9,8\% dan tertingi kedua pada tahun 2009 sebesar 5\% di kawasan Asia Tenggara. Sedangkan posisi ekonomi Indonesia dengan indikator pertumbuhan PDB peringkat ke empat pada tahun 2008 sebesar $6,1 \%$ dan peringkat ke tiga tahun 2009 sebesar $4,3 \%$. Dari kedua indikator ekonomi tersebut yaitu laju inflasi dan pertumbuhan PDB, maka dibutuhkan suatu kebijakan yang tepat guna menjaga kestabilan ekonomi.

Menurut Manullang (1993) untuk menciptakan perekonomian yang stabil terdapat tiga jenis kebijakan guna mencapai kondisi tersebut, yaitu kebijakan moneter, kebijakan fiskal dan kebijakan non moneter. Dari ketiga kebijakan yang ada, kebijakan moneter memegang peran sentral dalam mencapai dan memelihara kestabilan ekonomi makro. Hal ini sesuai dengan definisi kebijakan moneter menurut Milgate dalam Sabirin (2003), yaitu “...actions taken by central banks to affect monetary and other financial conditions in pursuit of the broader objectives of sustainable growth of real output, high employment, and price stability.".
Menurut Sukirno (1985) kebijakan moneter adalah kebijaksanaan yang bersifat makroekonomi oleh Bank Sentral bertujuan untuk mempengaruhi tingkat kegiatan ekonomi dengan mengawasi Jumlah Uang Beredar (JUB), atau tingkat suku bunga. Kebijakan moneter merupakan kebijakan yang relatif mandiri, terlepas dari kondisi maupun kebijakan di sektor keuangan. Hal ini didasarkan bahwa bank sentral memiliki kontrol yang nyaris sempurna terhadap penawaran uang sehingga dalam teori moneter penawaran uang dianggap bersifat eksogen. Sehingga dalam bentuk sederhananya kebijakan moneter diartikan sebagai pergeseran kurva LM dalam model IS-LM yang disebabkan oleh perubahan eksogen pada suplai uang melalui intervensi bank sentral. Kebijaksanaan moneter akan menaikkan JUB selama perekonomian mengalami resesi dan kemandegan untuk merangsang pengeluaran dan sebaliknya membatasi atau mengurangi supply uang pada saat inflasi untuk mengurangi pengeluaran. Dapat dikatakan bahwa kebijaksanaan moneter merupakan suatu kebijaksanaan yang mengupayakan agar terjadi keseimbangan antara penawaran dan permintaan uang. Dimana keseimbangan jumlah uang beredar merupakan salah satu cermin fundamental perekonomian suatu negara. Penawaran uang lebih dikenal dengan JUB (Money Supply) dan tingkat perubahannya ditentukan oleh interaksi pelaku ekonomi. Dengan mengendalikan JUB maka laju inflasi yang terjadi dapat dikontrol agar tidak terjadi lonjakan kenaikan harga yang sangat tinggi.

Dalam Ascarya (2005) fasilitas diskonto adalah fasilitas kredit (dan/atau simpanan) yang diberikan oleh bank sentral kepada bank-bank dengan jaminan surat-surat berharga dan tingkat diskonto yang ditetapkan oleh bank sentral sesuai dengan arah kebijakan 
moneter. Tinggi rendahnya tingkat diskonto akan mempengaruhi permintaan kredit dari bank. Fasilitas diskonto juga merupakan patokan suku bunga bagi bank untuk penetapan suku bunga pinjaman dan suku bunga kredit.

Kebijakan Bank Indonesia dengan menaikkan tingkat giro wajib minimum (GWM) dari 5\% dinaikkan menjadi $7,5 \%$ yang tertuang dalam peraturan $\mathrm{BI}$ No 10/25/PBI/2008 tanggal 14 Oktober 2008. Harapannya dilaksanakan kebijakan menaikkan tingkat GWM yaitu untuk mengurangi JUB dengan jalan meningkatkan likuiditas perbankan. Dengan adanya penurunan JUB diharapkan dapat menekan tingkat inflasi sehingga dapat mewujudkan perekonomian yang relatif lebih stabil.

Dari penjelasan diatas, kebijakan moneter memegang peran yang sangat sentral guna menjaga kestabilan makro ekonomi sehingga peneliti mengangkat judul "Efektifitas Kebijakan Moneter Terhadap Inflasi Di Indonesia". Karena dalam setiap Negara dibutuhkan suatu kestabilan ekonomi, sehingga perlu adanya kebijakan moneter yang tepat dan cepat guna mewujudkan kestabilan ekonomi tersebut. Dari judul yang diangkat peneliti ingin melihat apakah kebijakan moneter yang telah ditetapkan secara efektif berpengaruh terhadap inflasi di Indonesia.

Berdasarkan uraian diatas maka penulis bertujuan mengkaji kebijakan moneter melalui discount rate dan Giro Wajib Minimum oleh Bank Sentral serta inflasi sebelumnya mempengaruhi tingkat inflasi, dan kebijakan moneter melalui discount rate dan Giro Wajib Minimum serta inflasi sebelumnya secara apakah efektif mempengaruhi tingkat inflasi.

\section{TINJAUAN PUSTAKA}

Nelson dalam jurnal penelitiannya yang berjudul "Monetary Policy and
Stagflation in the UK', mengestimasikan model makroekonomi Keynesian Baru di UK dengan data selama 40 tahun. Hasil penelitiannya adalah estimasi parameter yang dilakukan signifikan dan dapat diinterprestasikan. Nelson berpendapat bahwa trade-off kurva Philips dalam jangka panjang tidak terlalu rumit, dan argumentasi Nelson "aturan kebijakan tidak akan diikuti karena kebijakan moneter mengabaikan arti penting jangka pendek dan jangka panjang dalam mengontrol inflasi".

Gersbach dalam penelitianya yang berjudul "Signaling Competence by Central Banks: Monetary Targeting or Inflation Targeting?", menyarankan bahwa inflation targeting untuk diterapkan karena dengan kebijakan tersebut lebih cepat direspon oleh masyarakat serta harus diikuti transparansi Bank Sentral mengenai informasi goncangan makroekonomi.

Dalam Warjiyo (2003), mekanisme transmisi melalui suku bunga menekankan bahwa kebijakan moneter dapat mempengaruhi permintaan agregat melalui jalur perubahan suku bunga. Ascarya (2005), penetapan suku bunga merupakan instrumen langsung bank sentral berupa penetapan tingkat suku bunga baik untuk pinjaman maupun simpanan di dalam system perbankan.

Dalam Sugiyono (2004), kebijakan GWM merupakan kebijakan yang tidak langsung, karena dalam mekanisme transmisi kebijakan GWM tidak bisa secara langsung mempengaruhi tingkat harga.

\section{METODE PENELITIAN}

Sampel data yang digunakan dalam penelitian ini adalah data kuartal I tahun 1985 sampai kuartal I tahun 2010 terdiri dari tingkat inflasi, discount rate dan reserve requirement policy (kebijakan cadangan minimum). Alasan dengan digunakannya data time series 
dari kuartal I tahun 1985 sampai kuartal I 2010 adalah pada tahun setelah dikeluarkannya paket oktober 1998 kebijakan reserve requirement perubahannya sangat tinggi, berikutnya kebijakan moneter melalui reserve requirement tidak mudah untuk diubahubah karena kebijakan ini melibatkan banyak lembaga dan kebijakan ini bersifat jangka panjang.

Alat analisis yang digunakan yaitu analisis regresi. Analisa regresi dilakukan untuk melihat pengaruh variabel bebas terhadap variabel terikat baik secara parsial maupun bersamasama. Dalam penelitian ini kebijakan moneter melalui discount rate dan GWM tidak berpengaruh secara langsung, dengan demikian perlu melihat pengaruh dari variabel yang mempengaruhi secara langsung terhadap inflasi yaitu JUB. Karena apabila variabel yang berpengaruh langsung yaitu JUB tidak berpengaruh signifikan terhadap inflasi maka variabel yang berpengaruh tidak langsung yaitu discount rate dan GWM juga tidak berpengaruh signifikan terhadap inflasi. Adapun tahapan yang dilakukan adalah:

Tahapan pertama yang perlu diketahui adalah melihat pengaruh JUB terhadap inflasi. Berikut persamaan JUB terhadap inflasi:

$\mathrm{M} \times \mathrm{V}=\mathrm{P} \times \mathrm{T}$

Dari persamaan (1) diatas

diturunkan menjadi:

$\mathrm{P}=\mathrm{V} / \mathrm{T} \times \mathrm{M}$

Dalam jangka pendek $\mathrm{V}$ dan $\mathrm{T}$ diasumsikan tetap pada kondisi kesempatan kerja penuh, sehingga diperoleh persamaan baru:

$\mathrm{P}=\alpha \times \mathrm{M}$

Dimana $\mathrm{P}$ merupakan tingkat harga, $\alpha$ merupakan konstanta dan $\mathrm{M}$ merrupakan jumlah uang beredar. Dari persamaan (3), dapat disusun sebuah persamaan regresi sebagai berikut: Inflasi $=\beta_{0}+\beta_{1}(\mathrm{JUB})+\mathrm{e}$
Tahapan kedua yang perlu diketahui adalah melihat dari discount rate dan GWM terhadap JUB. Telah dijelaskan di bab II sebelumnya bahwa JUB dipengaruhi oleh money multiplier, dan besarnya money multiplier dipengaruhi oleh discount rate dan GWM. Berikut persamaan discount rate dan GWM terhadap JUB:

$\mathrm{M}=\mathrm{f}(m m, H)$

$\mathrm{M}=\mathrm{f}($ discount rate, $\mathrm{GWM})$

$m m=\frac{c u+1}{c u+r e}$

Dari persamaan (6), dapat disusun sebuah persamaan regresi sebagai berikut:

$\mathrm{JUB}=\beta_{0}+\beta 1($ discount rate $)+$ $\beta 2(\mathrm{GWM})+\mathrm{e}$......................... (7)

Untuk mengetahui besarnya pengaruh antara variabel bebas dengan variabel terikat baik secara parsial maupun simultan atau bersama-sama, maka metode yang digunakan adalah analisa Partial Adjustment Model (PAM), karena model ini sesuai dengan penelitian yang dilakukan, yaitu memasukkan inflasi sebelumnya diantara variabel bebas lainnya dan terdapat kelambanan kebijakan moneter untuk direspon oleh para pelaku ekonomi. Adapun tahapan yang akan dilakukan yaitu pertama, pembentukan model.

Penelitian ini dilihat dari sudut pandang monetaris, adapun dasar persamaan yang digunakan dalam penelitian adalah sebagai berikut:

$\mathrm{M} \times \mathrm{V}=\mathrm{P} \times \mathrm{T}$

Dari persamaan (1) diatas diturunkan menjadi:

$\mathrm{P}=\mathrm{V} / \mathrm{T} \times \mathrm{M}$

Dalam jangka pendek $\mathrm{V}$ dan $\mathrm{T}$ diasumsikan tetap pada kondisi kesempatan kerja penuh, sehingga diperoleh persamaan baru:

$\mathrm{P}=\alpha \times \mathrm{M}$ atau $\mathrm{P}=\mathrm{F}(\mathrm{M})$ 
Dimana $\mathrm{P}$ merupakan tingkat harga, $\alpha$ merupakan konstanta dan $\mathrm{M}$ merrupakan jumlah uang beredar. Dari persamaan (10), $\mathrm{F}(\mathrm{M})$ dipengaruhi oleh money multiplier, dimana telah dijelaskan pada bab II sebelumnya bahwa besarnya money multiplier dipengaruhi oleh discount rate dan GWM, sehingga diperoleh persamaan sebagai berikut:

$\mathrm{F}(\mathrm{M})=\mathrm{f}(m m, H)$

$r e=\mathrm{r}\left(\mathrm{i}, \mathrm{i}_{\mathrm{D}}, \mathrm{r}_{\mathrm{R}}, \sigma\right)$

$m m=\frac{c u+1}{c u+r e}$

Dengan mensubtitusikan persamaan (12) ke persamaan (11) diperoleh persamaan baru:

$\mathrm{P}=\mathrm{F}(\mathrm{M})=\mathrm{f}(m m, H)$

Dari persamaan (13) diatas dapat dirumuskan model penelitian bahwa tingkat harga $(\mathrm{P})$ dipengaruhi besarnya rasio uang kartal dengan giro $(\mathrm{cu})$, rasio cadangan bank dengan deposito dan giro pada bank sentral (re) serta jumlah primer $(H)$. Akan tetapi dalam penelitian ini membatasi dengan variabel discount rate dan reserve requirment, dengan demikian dapat disusun persamaan sebagai berikut:

$\mathrm{P}=\mathrm{f}$ (discount rate, GWM)

Dari persamaan (14) merupakan fungsi yang dipakai dalam penelitian. Sesuai definisi tentang inflasi yang telah dijelaskan sebelumnya yaitu inflasi adalah perubahan tingkat harga umum secara terus menerus maka persamaan diatas perlu adanya perubahan sebagai berikut:

Inflasi $=\mathrm{f}($ discount rate, $\mathrm{GWM}) .$. (15)

Artinya perubahan tingkat harga atau inflasi dipengaruhi oleh besarnya perubahan discount rate dan GWM.

Sebelum melanjutkan analisa dengan metode maka terlebih dahulu variabel-variabel yang ditetapkan dimuka dibentuk suatu persamaan regresi. Persamaan regresi dalam penelitian ini adalah menggunakan PAM. Adapun persamaan PAM tersebut dapat ditulis sebagai berikut:

$\mathrm{Y}=\beta 0+\beta 1 \mathrm{X} 1+\beta 2 \mathrm{X} 2+\beta 3 \mathrm{Y}_{\mathrm{t}-1}+\mathrm{e}$. (16)

Dari persamaan (16) model PAM serta pada persamaan (15) diatas maka dapat disusun model penelitian sebagai berikut:

Inflasi $=\beta 0+\beta 1($ discount rate $)+$ $\beta_{2}(\mathrm{GWM})+\beta 3$ (Inflasi $_{\mathrm{t}-1}+\mathrm{e} \ldots$ (17)

Dimana: Inflasi $=$ satuannya $\%$; Discount rate $=$ satuannya $\% ;$ GWM = satuannya $\%$; Inflasi $\mathrm{t}-1=$ Inflasi sebelumnya satuannya \%; $\quad \beta 0=$ Konstanta; $\beta 1, \beta_{2}, \beta_{3}=\quad$ Koefisien regresi; $\mathrm{e}=$ Kesalahan pengganggu.

Dengan adanya kelambanan (inflasi, discount rate dan GWM), sehingga model ini disebut juga model autoregresi. Dimana dalam model melibatkan regresi variabel terikat atas lag variabel itu sendiri. Gujarati (1999), ada beberapa alasan mengapa model ini digunakan antara lain, yaitu alasan teknis dan kelembagaan. Dengan demikian koefisien jangka panjang untuk penyesuaiannya adalah sebagai berikut:

$\beta=\frac{\text { Coeficient Variabel Bebas }}{(1-\text { Coeficient Variabel Lag })}$

Untuk mengetahui variabel bebas yang mempengaruhi variabel terikat adalah dengan melihat besarnya probabilitas. Semakin kecil nilai probabilitas, maka semakin besar pula pengaruh yang ditimbulkan variabel bebas tersebut terhadap variabel terikat. Model ini juga di uji melalu uji statistik dan asumsi klasik.

\section{PEMBAHASAN}

Infrastruktur perekonomian Indonesia selama ini terutama sebelum krisis 1997 ternyata cukup rapuh. Karena ekonomi Indonesia terlalu didominasi oleh sektor usaha besar yang sangat tergantung kepada utang, khususnya utang luar negeri yang berjangka 
pendek. Dominasi sektor usaha besar ini terutama didukung oleh sektor perbankan nasional melalui pemberian kredit yang cenderung mengabaikan prinsip kehati-hatian. Rapuhnya ketahanan nasional juga didukung dengan besarnya ketergantungan barang impor.

Dari kondisi perekonomian yang rapuh tersebut, pada tahun 1997 Indonesia mulai mengalami krisis keuangan. Puncak terjadinya krisis ekonomi pada tahun 1998, kondisi tersebut berangsur-angsur membaik pada tahun-tahun berkutnya akan tetapi dampak dari krisis ekonomi tahun 1998 masih dirasakan. Belum lepas dari dampak krisis ekonomi tahun 1998. Berikut perkembangan kondisi inflasi serta kebijakan yang diambil Pemerintah guna mengatasi guncangan perekonomian.

Kondisi perekonomian Indonesia melalui salah satu indikator ekonomi yaitu inflasi mengalami guncangan ekonomi. Perkembangan inflasi kuartal I tahun 1985 hingga kuartal IV tahun 1997 masih satu digit dan relatif stabil. Pada kuartal berikutnya guncangan ekonomi dari sebelumnya mulai terasa dampaknya yaitu mulai kuartal I tahun 1998 tingkat inflasi sebesar 19.83\%, gejolak inflasi terjadi pada periodeperiode berikutnya yaitu $18.33 \%$ kuartal II 1998, puncak terjadinya krisis ekonomi terasa pada kuartal III 1998 yaitu sebesar $20.01 \%$, dan kuartal IV 1998 inflasi sebesar $4.78 \%$.

Pada periode berikutnya kuartal I 1999 inflasi sudah mengalami penurunan pada angka $4.76 \%$, dan periode berikutnya inflasi di Indonesia relatif stabil pada angka satu digit yaitu hingga kuartal III 2005 dan kuartal berikutnya infalsi kembali pada angka dua digit. Pada kuartal IV 2005 inflasi sebesar 10.34\%, kuartal I 2006 sebesar 16.9\%, kuartal II 2006 sebesar $15.51 \%$ dan kuartal III 2006 sebesar $14.87 \%$. Kuartal IV tahun 2006 inflasi menurun kembali pada angka satu digit, akan tetapi pada tahun 2008 inflasi naik kembali pada angka dua digit. Inflasi tahun 2008 lebih disebabkan oleh kondisi perekonomian dunia yang sedang mengalami krisis. Dan kondisi inflasi tersebut kembali turun pada level satu digit mulai kuartal I tahun 2009 hingga kuartal I tahun 2010.

Dengan melihat kondisi perekonomian diatas khususnya inflasi sebagai indikatornya, maka dapat dikatakan bahwa kondisi perekonomian Indonesia relatif kurang stabil dan pada tahun 1998 adalah masa-masa paling sulit yang dialami yaitu terjadinya krisis ekonomi. Sehingga untuk mengantisipasi kondisi perkekonomian yang kurang stabil dibutuhkan suatu kebijakan yang dapat meredam gejolak perekonomian baik dari kebijakan moneter.

Fluktusai kebijakan moneter discount rate dan GWM yang bertujuan untuk meredam perubahan tingkat inflasi. Karena dalam setiap kebijakan moneter akan mempengaruhi inflasi, khususnya dalam penelitian ini bertujuan untuk melihat pengaruh kebijakan moneter terhadap inflasi. Untuk kebijakan discount rate relatif lebih fluktuatif dibandingkan dengan kebijakan GWM. Karena kebijakan discount rate mudah direspon para pelaku ekonomi. Sedangkan kebijakan moneter GWM relatif dari tahun ke tahun cenderung konstan. Dari data tabel 4.2 penetapan nilai GWM dari tahun 1985 hingga tahun 2010 dilakukan senbanyak empat kali. Hal ini dilaksanakan guna menjaga konsistensi kebijakan dan untuk menjaga perekonomian jangka panjang.

Dalam penelitian ini kebijakan moneter melalui discount rate dan GWM tidak berpengaruh secara langsung, dengan demikian perlu melihat pengaruh dari variabel yang mempengaruhi secara 
langsung terhadap inflasi yaitu JUB. Karena apabila variabel yang berpengaruh langsung yaitu JUB tidak berpengaruh signifikan terhadap inflasi maka variabel yang berpengaruh tidak langsung yaitu discount rate dan GWM juga tidak berpengaruh signifikan terhadap inflasi. Adapun tahapan regresi yang dilakukan adalah sebagai berikut: Regresi Tahapan Pertama yaitu JUB terhadap Inflasi.

Berikut hasil regresi antara variabel terikat inflasi dengan variabel bebas JUB (tabel 1).

Dari hasil regresi yang disajikan pada tabel 1 dapat disusun persamaan regresi sebagai berikut:

Inflasi $=-10.615+2.617(\mathrm{JUB})+$ 4.004, Dimana masing-masing koefisien regresi variabel bebas menunjukkan besarnya perubahan yang akan terjadi pada variabel terikat akibat adanya perubahan sebesar satu satuan dari masing-masing variabel independent serta diasumsikan variabel bebas lainya tetap. Masing-masing koefisien variabel bebas dari persamaan hasil regresi dijelaskan sebagai berikut:

Inflasi = variabel terikat yang nilainya akan diprediksi oleh variabel bebas. Adapun yang menjadi variabel terikat dalam penelitian adalah tingkat inflasi di Indonesia yang besaran nilanya diprediksi oleh JUB.

$\beta_{0}=-10.615$ merupakan nilai konstanta, yaitu estimasi inflasi di Indonesia, jika variabel bebas JUB mempunyai nilai sama dengan nol, maka inflasi mengalami kenaikan sebesar 10.615 .

$\beta 1=2.617$ merupakan besarnya kontribusi variabel JUB yang mempengaruhi inflasi di Indonesia. Koefisien regresi $(\beta 1)$ sebesar 2.617 dengan tanda positif. Jika variabel JUB naik $1 \%$ maka inflasi di Indonesia akan naik sebesar $2.617 \%$.

$\mathrm{e}=4.004$ merupakan nilai residu atau kemungkinan kesalahan dari model persamaan regresi, yang disebabkan karena adanya kemungkinan variabel lainnya yang dapat mempengaruhi variabel inflasi tetapi tidak dimasukkan kedalam model persamaan.

Dengan melakukan uji statistik (uji $\mathrm{t}$ ), dengan derajat kebebasan (degree of freedom) sebesar 100 dan derajat kepercayaan $95 \%(\alpha=5 \%)$ diperoleh $\mathrm{t}_{\text {tabel }} \quad$ sebesar 1.98. Dengan membandingkaan nilai $t_{\text {hitung }}$ dan $t_{\text {tabel }}$, yaitu $4.078\left(\mathrm{t}_{\text {hitung }}\right)>1.98\left(\mathrm{t}_{\text {tabel }}\right)$ dapat disimpulkan bahwa variabel JUB berpengaruh signifikan terhadap inflasi di Indonesia dari kuartal I 1985 sampai kuartal I 2010. Untuk koefisien determinasinya sebesar 0.144 , artinya variabel bebas JUB dapat menjelaskan variabel terikat inflasi sebesar $14.4 \%$, sedangkan $85.6 \%$ dijelaskan variabel lainnya diluar variabel bebas yang ada pada model persamaan.

Regresi Tahapan Kedua yaitu discount rate dan GWM terhadap JUB. Berikut hasil regresi antara variabel terikat JUB dengan variabel bebas discount rate dan GWM (Tabel 2)

Tabel. 1. Hasil Regresi JUB Terhadap Inflasi

\begin{tabular}{cccc}
\multicolumn{1}{c}{ Variabel } & Koefisien Regresi & t Hitung & Sig. \\
\hline \multicolumn{1}{c}{ JUB } & 2.617 & 4.078 & 0.000 \\
Constanta & $:-10.615$ & & \\
Koefisien Determinasi $\left(\mathrm{R}^{2}\right)$ & $: 0.144$ & & \\
F-Statistic & $: 16.628$ & &
\end{tabular}


Tabel 2. Hasil Regresi Discount Rate dan GWM Terhadap JUB

\begin{tabular}{cccc}
\hline \multicolumn{1}{c}{ Variabel } & Koefisien Regresi & t Hitung & Sig. \\
\hline Discount Rate & -0.020 & -2.159 & 0.033 \\
$\quad$ GWM & -0.061 & -4.537 & 0.000 \\
Constanta & $: 6.058$ & & \\
Koefisien Determinasi $\left(\mathrm{R}^{2}\right)$ & $: 0.209$ & & \\
F-Statistic & $: 12.926$ & & \\
\hline
\end{tabular}

Dari hasil regresi yang disajikan pada tabel 2 dapat disusun persamaan regresi sebagai berikut:

$$
\begin{aligned}
\mathrm{JUB}= & 6.058-0.020(\text { discount rate })- \\
& 0.061(\mathrm{GWM})+0.56
\end{aligned}
$$

Dimana masing-masing koefisien regresi variabel bebas menunjukkan besarnya perubahan yang akan terjadi pada variabel terikat akibat adanya perubahan sebesar satu satuan dari masing-masing variabel independent serta diasumsikan variabel bebas lainya tetap. Masing-masing koefisien variabel bebas dari persamaan hasil regresi dijelaskan sebagai berikut:

JUB = variabel terikat yang nilainya akan diprediksi oleh variabel bebas. Adapun yang menjadi variabel terikat dalam penelitian adalah tingkat inflasi di Indonesia yang besaran nilanya diprediksi oleh discount rate dan GWM.

$\beta_{0}=6.058$ merupakan nilai konstanta, yaitu estimasi inflasi di Indonesia, jika variabel bebas discount rate dan GWM mempunyai nilai sama dengan nol, maka inflasi mengalami kenaikan sebesar 6.058.

$\beta_{1}=-0.020$ merupakan besarnya kontribusi variabel discount rate yang mempengaruhi inflasi di Indonesia. Koefisien regresi $(\beta 1)$ sebesar 0,020 dengan tanda negatif. Jika variabel discount rate naik $1 \%$ maka inflasi di Indonesia akan turun sebesar 0,020\%. Asumsi, variabel yang lain tetap.

$\beta_{2}=-0.061$ merupakan besarnya kontribusi variabel GWM yang mempengaruhi inflasi di Indonesia. Koefisien regresi ( $\beta 2)$ sebesar 0.061 dengan tanda negatif. Jika variabel GWM naik $1 \%$ maka inflasi di Indonesia akan turun sebesar $0.061 \%$. Asumsi, variabel yang lain tetap.

$\mathrm{e}=0.56$ merupakan nilai residu atau kemungkinan kesalahan dari model persamaan regresi, yang disebabkan karena adanya kemungkinan variabel lainnya yang dapat mempengaruhi variabel inflasi tetapi tidak dimasukkan kedalam model persamaan.

Dengan melakukan uji statistik (uji $\mathrm{t}$ dan uji $\mathrm{F}$ ) masing-masing adalah sebagai berikut: untuk uji t, dengan derajat kebebasan (degree of freedom) sebesar 99 dan derajat kepercayaan 95\% $(\alpha=5 \%)$ diperoleh $t_{\text {tabel }}$ sebesar 1.98, dengan membandingkaan nilai $t_{\text {hitung }}$ dan $\mathrm{t}_{\text {tabel }}$ masing-masing variabel yaitu untuk discount rate $2.159\left(\mathrm{t}_{\text {hitung }}\right)>1.98\left(\mathrm{t}_{\text {tabel }}\right)$ dan untuk GWM 4.537 (thitung $)>1.98$ $\left(\mathrm{t}_{\text {tabel }}\right)$ dapat disimpulkan bahwa variabel discount rate dan GWM secara parsial berpengaruh signifikan terhadap JUB di Indonesia dari kuartal I 1985 sampai kuartal I 2010. Sedangkan uji F, dengan $\mathrm{n}=101, \mathrm{k}=2$ dan derajat kepercayaan 95\% $(\alpha=5 \%)$ diperoleh $\mathrm{F}_{\text {tabel }}$ sebesar 3.07, dengan membandingkaan nilai $\mathrm{F}_{\text {hitung }}$ dan $\mathrm{F}_{\text {tabel }}$ yaitu $12.926\left(\mathrm{~F}_{\text {hitung }}\right)>$ $1.98\left(\mathrm{~F}_{\text {tabel }}\right)$, dapat disimpulkan bahwa variabel discount rate dan GWM secara simultan berpengaruh signifikan terhadap JUB di Indonesia dari kuartal I 1985 sampai kuartal I 2010. Untuk koefisien determinasinya sebesar 0.209 , artinya variabel bebas discount rate dan GWM dapat menjelaskan variabel terikat JUB sebesar $20.9 \%$, sedangkan $79.1 \%$ dijelaskan variabel lainnya diluar variabel bebas yang ada pada model persamaan. 
Analisis terakhir yaitu regresi dengan analisa Partial Adjustment Model. Dari data yang telah disajikan selanjutnya diolah menggunakan alat analisis regresi linier berganda dengan menggunakan pendekatan PAM. Model PAM digunakan dalam penelitian ini karena dalam pembentukan model awal perlu adanya penyesuaian, antara lain penyesuaian kelambanan mengenai kebijakan moneter yang lambat direspon perubahan tingkat harga. Tabel 3 merupakan hasil pengolahan data yang diperoleh sebelumnya.

Dari hasil regresi yang disajikan pada tabel 3 dapat disusun persamaan regresi sebagai berikut:

Inflasi $=1.689-0.056($ discount rate $)-$ $0.006(\mathrm{GWM})+0.764$ (Inflasi $_{\mathrm{t}}$ 1) +2.925

Dimana masing-masing koefisien regresi variabel bebas menunjukkan besarnya perubahan yang akan terjadi pada variabel terikat akibat adanya perubahan sebesar satu satuan dari masing-masing variabel independent serta diasumsikan variabel bebas lainya tetap. Masing-masing koefisien variabel bebas dari persamaan hasil regresi dijelaskan sebagai berikut:

Inflasi $=$ variabel terikat yang nilainya akan diprediksi oleh variabel bebas pada persamaan yang ada dalam penelitian. Adapun yang menjadi variabel terikat dalam penelitian adalah tingkat inflasi di Indonesia yang besaran nilanya diprediksi oleh discount rate, GWM dan inflasi sebelumnya. $\beta_{0}=1.689$ merupakan nilai konstanta, yaitu estimasi inflasi di Indonesia, jika variabel bebas yang terdiri dari variabel discount rate, GWM dan inflasi sebelumnya mempunyai nilai sama dengan nol, maka inflasi mengalami kenaikan sebesar 1.689.

$\beta_{1}=-0.056$ merupakan besarnya kontribusi variabel discount rate yang mempengaruhi inflasi di Indonesia. Koefisien regresi $(\beta 1)$ sebesar 0.056 dengan tanda negatif. Jika variabel discount rate naik $1 \%$ maka inflasi di Indonesia akan turun sebesar $0.056 \%$. Asumsi, variabel yang lain tetap.

$\beta_{2}=-0.006$ merupakan besarnya kontribusi variabel GWM yang mempengaruhi inflasi di Indonesia. Koefisien regresi ( $\beta 2)$ sebesar 0.006 dengan tanda negatif. Jika variabel GWM naik $1 \%$ maka inflasi di Indonesia akan turun sebesar $0.006 \%$. Asumsi, variabel yang lain tetap.

$\beta_{3}=0.764$ merupakan besarnya kontribusi variabel inflasi sebelumnya dalam mempengaruhi inflasi di Indonesia. Koefisien regresi ( $\beta 3$ ) sebesar 0.764 dengan tanda positif. Jika variabel inflasi sebelumnya naik $1 \%$ maka inflasi di Indonesia akan naik sebesar $0.764 \%$. Asumsi, variabel yang lain tetap.

$\mathrm{e}=2.925$ merupakan nilai residu atau kemungkinan kesalahan dari model persamaan regresi, yang disebabkan karena adanya kemungkinan variabel lainnya yang dapat mempengaruhi variabel inflasi di Indonesia dari kuartal I 1985 sampai kuartal I 2010.

Tabel. 3. Hasil Regresi Discount Rate, GWM dan Inflasi Sebelumnya Terhadap Inflasi

\begin{tabular}{lccc}
\multicolumn{1}{c}{ Variabel } & Koefisien Regresi & $\mathrm{t}$ Hitung & Sig. \\
\hline \multicolumn{1}{c}{ Discount Rate } & -0.056 & -1.109 & 0.270 \\
$\quad$ GWM & -0.006 & -0.085 & 0.932 \\
$\quad$ Inflasi $\mathrm{t}_{\mathrm{t}-1}$ & 0.764 & 10.659 & 0.000 \\
Constanta & $: 1.689$ & & \\
Koefisien Determinasi $\left(\mathrm{R}^{2}\right)$ & $: 0.555$ & & \\
Durbin Watson & $: 1.815$ & & \\
F-Statistic & $: 39.921$ & & \\
\hline
\end{tabular}


Dengan adanya kelambanan dari kebijakan moneter, maka untuk penyesuaian jangka panjang adalah sebagai berikut:

$$
\begin{aligned}
\beta & =\frac{\text { Coeficient Variabel Bebas }}{(1-\text { Coeficient Variabel Lag })} \\
\beta 1 & =\frac{-0.056}{(1-0.764)}=-0.237 \\
\beta 2 & =\frac{-0.006}{(1-0.764)}=-0.025
\end{aligned}
$$

Untuk penyesuaian kebijakan moneter untuk jangka panjang, yaitu berdasarkan hasil perhitungan penyesuaian diatas dapat dijelaskan apabila discount rate naik sebesar $1 \%$ maka inflasi turun sebesar $0.237 \%$. Sebaliknya apabila discount rate turun sebesar $1 \%$ dari maka inflasi naik sebesar $0.237 \%$. Sedangkan apabila GWM naik sebesar $1 \%$ maka inflasi akan turun sebesar $0.025 \%$, sebaliknya jika GWM turun sebesar $1 \%$ maka inflasi naik sebesar $0.025 \%$.

Dari hasil estimasi regresi yang telah dilakukan maka perlu adanya pengujian terhadap hasil, adapun pengujian yang dilakukan adalah sebagai berikut: Hasil $t_{\text {hitung menunjukkan }}$ discount rate dan GWM tidak berpengaruh signifikan terhadap inflasi di Indonesia, hanya inflasi tahun sebelumnya yang berpengaruh signifikan.

Dengan melihat nilai F-hitung dapat diketahui bahwa variabel bebas secara bersama-sama atau simultan berpengaruh signifikan terhadap inflasi dengan probabilitas sebesar 0.000 .

Nilai koefisien determinasi sebesar 0.555 . Artinya variabel bebas discount rate, GWM dan inflasi sebelumnya dapat menjelaskan variabel terikat inflasi sebesar $55.5 \%$, sedangkan $44.5 \%$ dijelaskan variabel lainnya diluar variabel bebas yang ada pada model persamaan penelitian yang dilakukan. Hasil uji asumsi klasik dari model ini dinyatakan lolos.

Dengan melihat hasil penelitian diatas bahwa kebijakan moneter secara parsial tidak efektif berpengaruh langsung terhadap inflasi dari kuartal I tahun 1985 sampai dengan kuartal I tahun 2010. Meskipun hubungan dari masing-masing kebijakan moneter adalah negatif. Akan tetapi kebijakan moneter dapat mempengaruhi inflasi lebih efektif 1985 sampai dengan kuartal I tahun 2010 apabila dilakukakan secara bersama-sama atau simultan.

\section{PENUTUP}

Dari hasil uji secara parsial diketahui bahwa kebijakan moneter melalui discount rate dan GWM memiliki hubungan negatif dengan inflasi di Indonesia dari kuartal I 1985 sampai dengan kuartal I 2010. Akan tetapi kebijakan moneter tersebut tidak berpengaruh secara langsung terhadap inflasi dari kuartal I 1985 sampai dengan kuartal I 2010 karena kebijakan moneter discount rate dan GWM terlebih dahulu melalui variabel antara JUB. Sedangkan untuk inflasi periode sebelumnya memiliki hubungan positif dan signifikan terhadap inflasi di Indonesia dari kuartal I 1985 sampai dengan kuartal I 2010. Adapun besarnya koefisien masing-masing variabel adalah -0.056 untuk discount rate, -0.006 untuk GWM dan 0.764 untuk inflasi sebelumnya.

Dari hasil uji secara simultan diketahui bahwa kebijakan moneter melalui discount rate, GWM dan inflasi sebelumnya memiliki pengaruh terhadap inflasi di Indonesia dari kuartal I 1985 sampai dengan kuartal I 2010. Adapun besarnya tingkat signifikansi secara 
simultan kebijakan moneter adalah 0.000 .

Dari hasil penelitian diketahui bahwa besarnya nilai koefisien determinasi atau $\mathrm{R}^{2}$ adalah sebesar 0.555. Artinya faktor-faktor yang mempengaruhi inflasi di Indonesia dari kuartal I 1985 sampai dengan kuartal I 2010 dapat dijelaskan oleh kebijakan moneter discount rate, GWM dan inflasi periode sebelumnya dengan prosentase $55.5 \%$ dan sisanya $44.5 \%$ dijelaskan oleh variabel lain diluar variabel yang ada dalam penelitian.

Sesuai hasil penelitian, perlu adanya kebijakan yang efektif dengan tidak melupakan jangka panjang. Saran yang dapat peneliti berikan adalah keterbukaan informasi tentang aspekaspek moneter seperti arah kebijakan moneter baik dalam jangka pendek maupun jangka panjang, sehingga nantinya kebijakan moneter yang telah ditetapkan dapat direspon oleh pelaku ekonomi dan kebijakan moenter menjadi lebih efektif.

Diharapkan bagi peneliti selanjutnya dapat mengkaji dengan menggunakan metode pendekatan lainnya sebagai perbandingan dan menjelaskan faktor-faktor yang dapat mempengaruhi inflasi di Indonesia. Karena masalah inflasi adalah permasalahan riil yang tidak terhindarkan dalam perekonomian. Sehingga nantinya dapat memberikan masukan kepada pemegang otoritas moneter dalam mengambil kebijakan.

\section{DAFTAR PUSTAKA}

Ascarya. 2005. Instrumen-instrumen Pengendalian Moneter. Cetakan 2. Jakarta: Pusat Pendidikan dan Studi Kebanksentralan (PPSK) BI.
Asian Development Bank, Outlook database, staff estimates, 2010.

Bank Indonesia, Statistik Ekonomi dan Keuangan Indonesia, berbagai tahun.

Dornbusch, Rudiger dan Fisher Stanley. 1995. Makroekonomi. Edisi 4. Terjemahan J. Mulyadi. Jakarta: Erlangga.

Gersbach, Hans and Volker Hahn. 2002. Signaling Competence by Central Banks: Monetary Targeting or Inflation Targeting.

Ghozali, Imam. 2001. Aplikasi Analisis Multivariate dengan Program SPSS. Semarang: Badan Penerbit Universitas Diponegoro.

Gujarati, Damodar. 1999. Ekonometrika Dasar. Terjemahan Sumarno Zain. Editor Gunawan Hutauruk. Jakarta: Erlangga.

International Monetary Fund, International Financial Statistics, 2007

Manullang. 1993. Pengantar Ekonomi Moneter. Cetakan 13. Medan: Ghalia Indonesia.

Manurung, Mandala dan Prathama Rahardja. 2004. Uang, Perbankan, dan Ekonomi Moneter. Jakarta: Penerbitan Fakultas Ekonomi Universitas Indonesia.

Murni, Asfia. 2006. Ekonomika Makro. Cetakan pertama. Bandung: PT. Refika Aditama.

Nelson, Edward and Kalin Nikolov. 2004. Monetary Policy and 
Stagflation in the UK. Journal of Money, Credit and Banking. Vol. 36 no. 3 part 1 (June 2004): 293318.

Sabirin, Syahril. 2003. Perjuangan Keluar dari Krisis. Edisi 1, cetakan 1. Yogyakarta: BPFEYogyakarta.

Slavin, Stephen L. 1999. Macroeconomics. $5^{\text {th }}$ ed. United States: Irwin/McGraw-Hill.

Sugiyono, F.X. 2004. Instrumen Pengendalian Moneter: Operasi Pasar Terbuka. Jakarta: Pusat Pendidikan dan Studi Kebanksentralan (PPSK) BI.

Sukirno, Sardono. 2002. Pengantar Teori Makroekonomi. Edisi 1, Cetakan 13. Jakarta: PT. Grafindo Persada.

Waluyo, Dwi Eko. 2006. Ekomomika Makro. Edisi Revisi. Cetakan keempat. Malang: Universitas Muhammadiyah Malang.

Warjiyo, Perry dan Solikin. 2003. Kebijakan Moneter di Indonesia. Jakarta: Pusat Pendidikan dan Studi Kebanksentralan (PPSK) BI. 